\title{
Dietary Bioactive Compounds and Human Health and Disease
}

\author{
Sonia González ${ }^{1,2}$ (D) \\ 1 Department of Functional Biology, University of Oviedo, 32762 Oviedo, Spain; soniagsolares@uniovi.es; \\ Tel.: +34-985-104-209 \\ 2 Diet, Microbiota and Health Group, Instituto de Investigación Sanitaria del Principado de Asturias (ISPA), \\ 32762 Oviedo, Spain
}

Received: 16 January 2020; Accepted: 21 January 2020; Published: 29 January 2020

check for updates

In the last century, solid scientific evidence has demonstrated the role of nutritional compounds in the maintenance of health. However, in the last few decades, the interest in the nutritional field has gone a step forward, searching for novel compounds with the capacity to reduce the risk of non-communicable diseases. In this context, the special issue of nutrients entitled "Dietary bioactive compounds and human health and disease" compiles 4 revisions and 12 original articles reporting the most novel findings of the impact of different bioactive compounds on a wide range of pathologies as different as non-alcoholic fatty liver disease, cancer, and obesity. This issue covers a hot topic, which is evidenced by the large number of recent articles compiled in the reviews.

There is no consensus in the literature to define the term "bioactive compound", although within the most widely accepted denominations they are "compounds which have the capability and the ability to interact with one or more component(s) of living tissue by presenting a wide range of probable effects" [1]. Despite that this concept has been highly dynamic over time, this collection of review articles provides a useful summary, especially of the progress in the roles of phenolic compounds on health.

Regarding polyphenols, revisions of different kinds have been compiled. Den Hartogh et al. summarizes in vitro and in vivo the most relevant studies examining the nephroprotective effects of resveratrol. For this purpose, the authors list the major articles studying the impact of resveratrol administration on each of the cell types present in the nephron, depending on the concentration administered and the duration of the intervention [2]. Mayo et al. review the potential role of microorganisms as mediators in the biosynthesis of equol, one of the main metabolites of isoflavones, discussing their possible application to various pathologies and proposing possible modes of action for these compounds [3]. This is a very interesting work that shows that, regardless of the daizein consumed with the diet, the amount of bioactive compounds generated from it has a high inter-individual variation, which may be conditioned by the human intestinal microbiota. Finally, Dabeek et al. extensively review the existing literature on the bioavailability and bioactivity of dietary quercetin and kaempferol, two of the most consumed polyphenols [4,5], assessing their possible impact on cardiovascular health in humans [4]. Together with phenolics, sulphur-containing compounds have also accumulated a large body of scientific evidence of their protective role against pathologies related to oxidative stress, inflammation, and the immune system, many of which are summarized by Rodrigues et al. [6].

At the metabolic level, in animal models, Lim et al. find a decrease in insulin resistance, triglycerides and LDL and total cholesterol, white fat tissue weights, and leptin levels after supplementation with cyanidine-3-O-galactoside-enriched Aronia melanocarpa extract [7]. Although these results are not yet extrapolated to humans, the high content in phenolic compounds of this berry and its antioxidant capacity, in comparison to other fruits [8], makes it interesting in the study of oxidative stress-related pathologies. In the same line, Zhu et al. propose konjac mannan oligosaccharides as an alternative 
dietary intervention for the delay of obesity, diabetes, and their associated complications [9] and Mun et al. propose the Curcuma Longa water extract as a potential agent against non-alcoholic fatty liver disease through modulating fatty acid uptake [10].

In addition to these vegetable compounds, this issue includes novel findings regarding the implication of bioactive peptides, amino acids, and fatty acids in different metabolic outcomes. Mas-Capdevila et al. raise interesting hypotheses about how the resistance of peptides to gastric digestion may modulate their antihypertensive effect [11], adding a novel approach to previous work about this topic [12,13]. At this point, factors such as bioavailability, synergistic effects between these compounds, or their interaction with other food components, are essential to deepening the knowledge of bioactive compounds on health [4]. In this regard, Mc Veay et al. evaluate the synergic effect of lauric acid and L-tryptophan on fasting glucose, insulin, and glucagon in healthy men [14].

Among the most innovative works, the findings of Lim Y et al. report the beneficial effect at a vascular level and blood pressure in chronic smokers after supplementation with Sanghuang-Danshen bioactive compounds [15], and Kuban-Jankowska et al. identify docosahexaenoic (DHA) acid as a potential agent in breast cancer prevention [16].

If some of the preliminary findings compiled in this special issue are confirmed in the future, they could be of great interest to the agro-food industry. To this end, there is a need to identify optimal extraction methods. This is the case with Altieri et al., who carry out a pilot study to obtain high value-added products for the industry by means of the transformation of by-products of pomegranate juice through a hydro-alcoholic extraction [17]. The obtaining of algae or plant-derivate products with potential effects on different diseases such as infections in the upper respiratory tract, [18] or even in non-communicable diseases such as cancer [16] or non-alcoholic fatty liver disease [10], could be a promising way to obtain new agents to fight these pathologies.

Conflicts of Interest: The author declare not conflict of interest.

\section{References}

1. Guaadaoui, A.; Benaicha, S.; Elmajdoub, N.; Bellaoui, M.; Hamal, A. What is a bioactive compound? A combined definition for a preliminary consensus. Int. J. Food Sci. Nutr. 2014, 3, 17-179. [CrossRef]

2. Den Hartogh, D.J.; Tsiani, E. Health Benefits of Resveratrol in Kidney Disease: Evidence from In Vitro and In Vivo Studies. Nutrients 2019, 11, 1624. [CrossRef] [PubMed]

3. Mayo, B.; Vázquez, L.; Flórez, A.B. Equol: A Bacterial Metabolite from The Daidzein Isoflavone and Its Presumed Beneficial Health Effects. Nutrients 2019, 11, 2231. [CrossRef] [PubMed]

4. Dabeek, W.M.; Marra, M.V. Dietary Quercetin and Kaempferol: Bioavailability and Potential Cardiovascular-Related Bioactivity in Humans. Nutrients 2019, 11, 2288. [CrossRef] [PubMed]

5. Erdman, J.W.; Balentine, D.; Arab, L.; Beecher, G.; Dwyer, J.T.; Folts, J.; Harnly, J.; Hollman, P.; Keen, C.L.; Mazza, G.; et al. Flavonoids and Heart Health: Proceedings of the ILSI North America Flavonoids Workshop, May 31-June 1, 2005, Washington, DC. J. Nutr. 2007, 137, 718S-737S. [CrossRef] [PubMed]

6. Rodrigues, C.; Percival, S. Immunomodulatory Effects of Glutathione, Garlic Derivatives, and Hydrogen Sulfide. Nutrients 2019, 11, 295. [CrossRef] [PubMed]

7. Lim, S.-M.; Lee, H.S.; Jung, J.I.; Kim, S.M.; Kim, N.Y.; Seo, T.S.; Bae, J.-S.; Kim, E.J. Cyanidin-3-O-Galactoside-Enriched Aronia melanocarpa Extract Attenuates Weight Gain and Adipogenic Pathways in High-Fat Diet-Induced Obese C57BL/6 Mice. Nutrients 2019, 11, 1190. [CrossRef] [PubMed]

8. Jakobek, L.; Šeruga, M.; Medvidović-Kosanović, M.; Novak, I. Antioxidant activity and polyphenols of Aronia in comparison to other berry species. Agric. Conspec. Sci. 2007, 72, 301-306.

9. Zhu, D.; Yan, Q.; Li, Y.; Liu, J.; Liu, H.; Jiang, Z. Effect of Konjac Mannan Oligosaccharides on Glucose Homeostasis via the Improvement of Insulin and Leptin Resistance In Vitro and In Vivo. Nutrients 2019, 11, 1705. [CrossRef] [PubMed]

10. Mun, J.; Kim, S.; Yoon, H.-G.; You, Y.; Kim, O.-K.; Choi, K.-C.; Lee, Y.-H.; Lee, J.; Park, J.; Jun, W. Water Extract of Curcuma longa L. Ameliorates Non-Alcoholic Fatty Liver Disease. Nutrients 2019, 11, 2536. [CrossRef] [PubMed] 
11. Mas-Capdevila, A.; Iglesias-Carres, L.; Arola-Arnal, A.; Aragonès, G.; Aleixandre, A.; Bravo, F.; Muguerza, B. Evidence that Nitric Oxide is Involved in the Blood Pressure Lowering Effect of the Peptide AVFQHNCQE in Spontaneously Hypertensive Rats. Nutrients 2019, 11, 225. [CrossRef] [PubMed]

12. Quirós, A.; Contreras, M.D.M.; Ramos, M.; Amigo, L.; Recio, I. Stability to gastrointestinal enzymes and structure-activity relationship of $\beta$-casein-peptides with antihypertensive properties. Peptides 2009, 30, 1848-1853. [CrossRef] [PubMed]

13. Hong, F.; Ming, L.; Yi, S.; Zhanxia, L.; Yongquan, W.; Chi, L. The antihypertensive effect of peptides: A novel alternative to drugs? Peptides 2008, 29, 1062-1071. [CrossRef] [PubMed]

14. McVeay, C.; Fitzgerald, P.C.E.; Horowitz, M.; Feinle-Bisset, C. Effects of Duodenal Infusion of Lauric Acid and L-Tryptophan, Alone and Combined, on Fasting Glucose, Insulin and Glucagon in Healthy Men. Nutrients 2019, 11, 2697. [CrossRef] [PubMed]

15. Lim, Y.; Song, T.-J.; Hwang, W.; Kim, J.Y.; Lee, D.; Kim, Y.-J.; Kwon, O. Synergistic Effects of Sanghuang-Danshen Bioactives on Arterial Stiffness in a Randomized Clinical Trial of Healthy Smokers: An Integrative Approach to in silico Network Analysis. Nutrients 2019, 11, 108. [CrossRef] [PubMed]

16. Kuban-Jankowska, A.; Gorska-Ponikowska, M.; Sahu, K.K.; Kostrzewa, T.; Wozniak, M.; Tuszynski, J. Docosahexaenoic Acid Inhibits PTP1B Phosphatase and the Viability of MCF-7 Breast Cancer Cells. Nutrients 2019, 11, 2554. [CrossRef] [PubMed]

17. Altieri, F.; Cairone, F.; Giamogante, F.; Carradori, S.; Locatelli, M.; Chichiarelli, S.; Cesa, S. Influence of Ellagitannins Extracted by Pomegranate Fruit on Disulfide Isomerase PDIA3 Activity. Nutrients 2019, 11, 186. [CrossRef] [PubMed]

18. Evans, M.; Falcone, P.H.; Crowley, D.C.; Sulley, A.M.; Campbell, M.; Zakaria, N.; Lasrado, J.A.; Fritz, E.P.; Herrlinger, K.A. Effect of a Euglena gracilis Fermentate on Immune Function in Healthy, Active Adults: A Randomized, Double-Blind, Placebo-Controlled Trial. Nutrients 2019, 11, 2926. [CrossRef] [PubMed]

(C) 2020 by the author. Licensee MDPI, Basel, Switzerland. This article is an open access article distributed under the terms and conditions of the Creative Commons Attribution (CC BY) license (http://creativecommons.org/licenses/by/4.0/). 